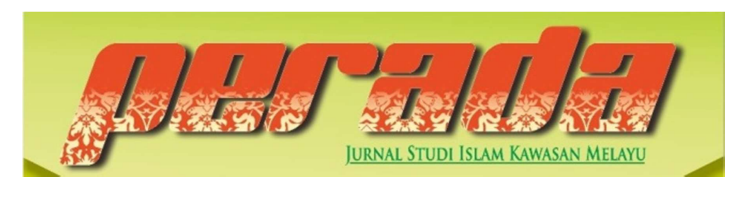

\author{
Perada: Jurnal Studi Islam Kawasan Melayu \\ ISSN 2656-7202 (P) ISSN 2655-6626 (0) \\ Volume 3 Nomor 2, Juli-Desember 2020 \\ DOI: https://doi.org/10.35961/perada.v3i2.143
}

\title{
KONTRADIKSI PERHIASAN TUBUH WANITA: TELAAH PENAFSIRAN MUHAMMAD SYAHRUR
}

\author{
Sefri Auliya \\ Universitas Islam Negeri Imam Bonjol Padang \\ archelazizah@gmail.com \\ Hidayatul Azizah Gazali \\ Universitas Islam Negeri Imam Bonjol Padang \\ zheezhy@gmail.com
}

\begin{abstract}
ABSTRAK
Penafsiran teks al-Qur'an menjadi salah satu fokus kajian bagi Muhammad Syahrur. Meskipun pola berfikirnya dianggap kontroversi, namun tetap mencoba untuk merumuskan konsepnya sendiri. Menurutnya, produktivitas umat Islam mandul di era modern karena masih dipenuhi oleh taqlid, fanatisme dan indoktrinasi pemikiran di masa klasik, padahal Allah SWT telah meninggikan posisi akal supaya selalu bisa menghasilkan karya yang relevan dengan perkembangan zaman. Oleh karena itu, Syahrur melakukan pembacaan ulang terhadap kitab suci dengan merumuskan pembagian perhiasan tubuh wanita menjadi tiga, yaitu perhiasan benda, perhiasan tempat dan perhiasan gabungan antara keduanya. Baginya, perhiasan tubuh wanita menjadi pembahasan penting yang akan membawa pada pemahaman tentang aurat wanita. Akan tetapi, pembagian ini menunjukkan kelonggaran dan kerancuan berfikir Syahrur tanpa didasari keilmuan yang memadai. Selain itu, penafsirannya juga dianggap bertentangan dengan pendapat mayoritas ulama.
\end{abstract}

Abstract: Abstract: Muhammad Syahrur is a contemporary figure who studies the interpretation of the Qur'anic text. Although the mindset is considered controversial, he still tries to formulate his own concept. According to him, the productivity of Muslims is barren in the modern era because it is still filled with taqlid, fanatism and indoctrination of thught in the classical period, whereas Allah SWT has elevated the position of mind so that it can always produce work that is relevant to the times. Therefore, Syahrur re-read the holy book by formulating the divisions of women's body jewelry into three, namely jewelry, place jewelry and combined between the two. For him, women's body jewelry became an important discussion that would lead to an understanding of women's genitalia. However, this divisions show the laxity and ambiguity of Syahrur's thought without being based on adequate knowledge. In addition, his interpretation is also considered contradict the opinions of the majority of scholars. 
Kata Kunci: syahrur, perhiasan, tubuh, wanita

\section{PENDAHULUAN}

Penafsiran teks al-Qur'an pasti selalu bersifat personal, temporal, kontekstual, dan relatif karena merupakan hasil olah pikir manusia. ${ }^{1}$ Dalam perkembangannya banyak sekali ditemukan kreativitas dan inovasi penafsiran yang senantiasa menyesuaikan dengan situasi dan kondisi yang mengitari para mufassir. Ini juga menjadi bukti kalau penafsiran relevan dengan sifat al-Qur'an yang shalih likulli zaman wa makan.

Ketika pewahyuan al-Qur'an selesai atau tepatnya setelah Nabi Muhammad SAW wafat, maka bermunculanlah berbagai macam kitab tafsir dengan beragam metodo-logi yang ditulis oleh para mufassir. Akan tetapi, metodologi penafsiran yang diguna-kan pada zaman klasik sampai di zaman pertengahan dianggap tidak menawarkan perspektif baru dalam kehidupan yang terus mengalami perubahan karena cenderung diambil dari warisan terdahulu dan bersifat pengulangan saja. Harus diakui bahwa fenomena tersebut berdampak pada kekhawatiran dunia Islam mengahadapi arus persaingan global yang sangat dinamis, sedangkan pemikiran dan peradaban Islam masih mengalami stagnasi. Fungsi al-Qur'an sebagai pegangan hidup sedikit demi sedikit tergerus oleh kegiatan interpretasi yang masih sangat tradisional, diskriminatif, dan jauh dari nilai-nilai sosial. Kalau hal-hal seperti ini dibiarkan terus terjadi, maka ditakutkan umat Islam akan semakin menjauhi al-Qur'an atau bahkan berpaling darinya.

Adanya gerakan pembaharuan dan kebangkitan Islam pada abad ke-18 khususnya di bidang pemikiran,

1 Adian Husaini dan Abdurrahman alBaghdadi, Hermeneutika dan Tafsir Al-Qur'an, (Jakarta: Gema Insani, 2007), h. 17 memberikan dampak yang signifikan terhadap meto-dologi penafsiran alQur'an. Tindakan reinterpretasi terhadap al-Qur'an yang menjadi sumber dari ajaran agama dan kehidupan perlu dilakukan supaya sesuai dengan kebutuhan zaman. Kehadiran sebuah metodologi baru sangat diperlukan sebagai jawaban dari berbagai permasalahan yang muncul di zaman sekarang yang dianggap belum terjawab secara tuntas. Oleh karena itu, muncullah model tafsir era modern kontemporer dengan memperke-nalkan berbagai cara dan pola baru dalam menginterpretasikan al-Qur'an.

Sejak masa awal kelahirannya, para tokoh dan pemikir tafsir di era modern kontemporer masih merujuk kepada metodologi mufassir dan kitab-kitab tafsir sebelumnya. Realita ini menunjukkan bahwa teks al-Qur'an yang dijelaskan dalam berbagai penafsiran terbaru senantiasa merujuk pada tradisi keilmuan masa lalu dan terus berkelanjutan. Akan tetapi, ada beberapa inovasi dan pembaharuan untuk menyesuaikan dengan kebutuhan umat karena al-Qur'an bukan diperuntukkan untuk masa tertentu saja namun berlaku sepanjang masa. ${ }^{2}$ Dalam memahami al-Qur'an dibutuhkan beragam disiplin ilmu supaya bisa terjadi integrasiinterkoneksi ilmu secara menyeluruh. ${ }^{3}$ Bahkan, seseorang yang hendak menafsirkan al-Qur'an tidak dibolehkan langsung membuat pernyataan sebelum mendiskusikannya dengan para ahli dan mempertimbangkan dengan matang pemikirannya. ${ }^{4}$

\footnotetext{
${ }^{2}$ Routraud Woelandt, 'Tafsir al-Qur'an Masa Awal Modern dan Kontemporer', dalam Jurnal Afkar, Edisi No. 18, Tahun 2004, h. 59-60

3 Abdul Mustaqim, Epistemologi Tafsir Kontemporer, (Yogyakarta: LKiS, 2012), h. 62

4 Muhammad Amin Abdullah, Metode Kontemporer dalam Penafsiran al-Qur'an', dalam Jurnal Studi Ilmu-Ilmu al-Qur'an dan Hadis, Vol. 13, No. 1, Januari 2012, h. 8
} 
Pada era tafsir modern kontemporer ini, sebenarnya banyak gagasan baru yang dibawa dan ditawarkan oleh para pemikir yang ikut berbicara tentang metode dan pendekatan tafsir. Adapun diantara tokoh yang sangat berpengaruh dalam hal ini diantaranya adalah Muhammad Syahrur. Pada prosesnya, Muhammad Syahrur diang-gap sebagai salah satu pemikir yang banyak mendapat kritikan terutama di awal mileni-um 2000. Asumsi tersebut diperkuat dengan kehadiran buku pertamanya tentang kajian teks al-Qur'an, yaitu al-Kitab wa al-Qur'an: Qira'ah Mu'ashirah. Dalam karyanya ini, Muhammad Syahrur mencoba untuk menawarkan beberapa gagasan baru konsep al-Qur'an yang berkaitan dengan berbagai diskursus keilmuan. Selain itu, buku yang diselesaikan dalam surveynya hampir selama 20 tahun ini bisa dikatakan sebagai karya magnum opus karena memberikan kontribusi yang luar biasa dalam kajian al-Qur'an, khususnya ketika menantang umat Islam untuk berani melakukan eksperimentasi pemikiran menggunakan pendekatan yang baru supaya bisa merespon berbagai problematika kontemporer. ${ }^{5}$

Pada perkembangannya, Syahrur pernah dituduh liberal, agen zionis, mungkar sunnah, bahkan kafir, karena ada kontradiksi pemahaman dengan para ulama terdahulu. ${ }^{6}$ Konsep berfikirnya sebagai seorang teknok-rat yang banyak terpengaruh budaya barat dan minim pengetahuan tentang agama juga teraplikasi dalam pembacaannya tentang kajian keislaman, salah satunya adalah tentang perhiasan tubuh wanita. Dalam kasus ini, Syahrur dianggap bisa merubah

${ }^{5}$ Abdul Mustaqim, 'Konsep Poligami Menurut Muhammad Syahrur', dalam Jurnal Studi Ilmu-Ilmu Al-Qur'an dan Hadis, Vol. 8, No. 1, Januari 2007, h. 47

${ }^{6}$ Gazi al-Taubah, 'Syahrur Yulawwi A'naq alNusus li Agrad Gair al-Ilmiyyah wa al-Taftaqiru ila alBara'ab', dalam Majalah al-Mujtama', No. 1302, 26 Mei 1998, h. 56 model hukum Islam, apalagi dengan adanya pembagian perhiasan tubuh wanita menjadi tiga, yaitu perhiasan benda, perhiasan tempat dan perhiasan gabungan antara keduanya, dimana nanti sangat erat kaitannya dengan batasan aurat wanita. Rumusan Syahrur ini dianggap terlalu mempertimbangkan budaya masyarakat, sehingga bisa bertentangan dengan teks alQur'an. ${ }^{7}$ Para ulama memang berbeda pendapat dalam menentukan bagian perhiasan tubuh wanita, tetapi tidak menge-nal istilah yaitu perhiasan benda, perhiasan tempat dan perhiasan gabungan antara keduanya.

Oleh karena itu, penafsiran alQur'an yang dilakukan oleh Syahrur khususnya tentang perhiasan tubuh wanita dirasa perlu untuk ditinjau ulangi karena sudah melen-ceng dari maksud al-Qur'an. Lebih berba-haya lagi ketika ditemukan perbedaan penafsiran dengan ulama yang memiliki disiplin keilmuan yang lebih memadai. Latar belakang keilmuannya sangat berpengaruh pada kerancuan berfikirnya, sehingga mem-berikan dampak yang nyata terhadap model penafsirannya.

Penelitian ini memakai pendekatan sosio-bistoris dan hermeneutik. Pendekatan sosio-bistoris berfungsi untuk mengenal lebih jauh tokoh yang diteliti dan bagaimana pemikirannya tentang tafsir al-Qur'an. Selain itu, juga menjelaskan kronologi dan dinamika perjalanan hidup seorang tokoh melalui studi kasus, telusur kepustakaan, atau penelitian fenomenologi. ${ }^{8}$ Bahkan, situasi yang melahirkan ide dari seorang tokoh bisa dilacak melalui pendekatan ini karena menghendaki informasi detail berupa asal dari sikap dan pemikiran tokoh, atau mazhab dan golongan yang

7 Abdul Aziz Azzam, al-Qawaid al-Fiqhiyyah, (Kairo: Dar al-Hadis, 2005), h. 174

8 Arief Furchan dan Agus Maimun, Studi Tokoh: Studi Penelitian Mengenai Tokoh, (Yogyakarta: Pustaka Pelajar, 2005), h. 64 
dianutnya. 9 Adapun pendekatan hermeneutik dalam hal ini berfungsi sebagai sistem interpretasi (system of interpretation) teks al-Qur'an, yaitu teknik memproduksi makna untuk memahami alQur'an dengan mengolah teks yang bisa hidup dalam berbagai konteks, atau menterjemahkan dan menjelaskan teks masa lalu ke dalam konteks kekinian. ${ }^{10}$

Adapun teknik analisis isi (content analysis) digunakan untuk menganalisa data-data dalam penelitian ini, yaitu semua informasi yang terekam dan berbagai jenis komunikasi yang dipakai, mesti dikaji melalui prosedur yang sistematis, baik itu dari dokumentasi, tulisan ilmiah, radio, televisi, dan lain-lain, ${ }^{11}$. Kemudian, idealnya juga harus ada analisis ilmiah tentang isi pesan dari suatu informasi dan komunikasi. ${ }^{12}$

\section{KARIR INTELEKTUAL MUHAM- MAD SYAHRUR}

Karir intelektual Syahrur dimulai dari pendidikan dasar dan menengah yang ditempuhnya di sekolah-sekolah tempat kelahirannya. Ketika usianya yang kesembilan belas pada tahun 1957, Syahrur memperoleh ijazah sekolah menengah di lembaga pendidikan Abd-al-Rabman alKawakibi, Damaskus. Setahun berikutnya, tepatnya pada bulan Maret 1958, atas beasiswa pemerintah ia berangkat ke Moskow, Uni Soviet (sekarang Rusia), untuk mempelajari Teknik Sipil dan selesai pada tahun 1964 dengan gelar Diploma. Kemudian, tahun 1965 pulang ke negara asalnya untuk menjadi tenaga pendidik di 65-67

${ }_{9}^{9}$ Imam Suprayogo dan Thabrani, Op.Cit., h.

10 Syafa'atun Almirzanah dan Sahiron Syamsuddin, Upaya Integrasi Hermeneutika dalam Kajian Qur'an dan Hadis (Teori dan Aplikasi), (Yogyakarta: Lembaga Penelitian UIN Sunan Kalijaga, 2012), h. 71

11 Arif Sukandi, Metode dan Analisis Penelitian, (Jakarta: PT. Glora Alsora Pratama, 1991), h. 48

12 Noeng Muhadjir, Metodologi Penulisan Kualitatif, (Yogyakarta: Rake Suarsiah, 2000), h. 68
Universitas Damaskus tepatnya pada Fakultas Teknik. ${ }^{13}$ Selain itu, Syahrur juga pernah diberi kesempatan oleh pihak Imperial College di London Inggris untuk melakukan penelitian, tapi akhirnya gagal terwujud karena putusnya hubungan diplomatik Syria dengan Inggris setelah kejadian "Perang Juni" antara Syria dan Israel. Dalam waktu yang tidak lama, Universitas Damaskus mengutusnya ke Irlandia, tepatnya Ireland National University untuk melanjutkan studinya menempuh program Magister dan Doktoral dalam bidang yang sama dengan spesialisasi Mekanika Tanah dan Geologi. Tahun 1969, Syahrur meraih gelar Master dan tiga tahun berikutnya, yaitu tahun 1972, ia menyelesaikan program Doktoralnya. Berbekal kompetensi keilmuan yang dimiliki, pada tahun itu juga Universitas Damaskus secara resmi mengangkat Syahrur sebagai dosen di Fakultas Teknik dengan mengampu bidang Mekanika Tanah dan Geologi. ${ }^{14}$

Hal yang menarik dari perjalanan intelektualnya adalah ketika Syahrur merasa kajian keislaman yang telah ada selama ini belum menyentuh persoalan kekinian. Umat Islam dianggap tertinggal dan masih hidup dalam bayang-bayang kejayaan masa lampau, sehingga pemikirannya pun ikut terpenjara dalam doktrin kebenaran ulama terdahulu padahal masih harus dikaji ulang di zaman sekarang. Sesuatu yang terkesan benar namun hakikatnya adalah salah. Ada berbagai usaha yang dilakukan untuk menunjukkan kesempurnaan ajaran Islam sebagai tata cara hidup, namun akhirnya gagal menjawab dilema yang terjadi karena tidak sampai pada pembahasan hal paling

13 Ahmad Zaki Mubarok, Pendabuluan; Pendekatan Strukturalisme Linguistik dalam Tafsir Kontemporer "ala" Mubammad Syabrur, (Yogyakarta: eLSAQ Press, 2007), h. 137-138

${ }_{14}$ M. Aunul Abied Shah dan Hakim Taufik, Islam Garda Depan: Mosaik Pemikiran Islam Timur Tengah, (Bandung: Mizan, 2001), h. 237 
mendasar. Akhirnya, Syahrur secara serius ikut serta dalam berbagai kajian ilmiah tentang keislaman. ${ }^{15}$

Ketika kuliah di Moskow, Syahrur mulai belajar dan mengagumi ide-ide Marxis. Selain itu, Syahrur juga banyak belajar dari Ja'far Dakk al-Bab teman ketika kuliah tentang dasar filsafat dan ilmu bahasa Arab. Ja'far memberikan pengaruh yang sangat besar terhadap perkembangan pola berfikir Syahrur. Penelitiannya tentang berbagai kosakata penting dalam al-Qur'an juga terinspirasi dari Ja'far. Diskusi yang intens dengan Ja'far semakin meyakinkan Syahrur untuk melakukan penggalian langsung terhadap teks al-Qur'an agar bisa menghasilkan gagasan dan ide baru. ${ }^{16}$

Kesibukan Syahrur di dunia kampus sebagai seorang pengajar tidak menghalanginya untuk menghasilkan berbagai karya tulisan yang sesuai dengan spesialisasinya, baik itu buku maupun artikel. Diantara karyanya yang terkenal adalah Teknik Pertanahan (Handasat alTurab) dan Teknik Fondasi Bangunan (Handasat al-Asasat, yang sudah tersebar di Damaskus dan dunia. ${ }^{17}$

Keunikan sosok Syahrur terlihat ketika dia mencurahkan perhatiannya untuk mengkaji beberapa hal penting tentang Islam dan al-Qur'an. Berbekal ilmu bahasa dan filsafat, Syahrur membuat sebuah kolaborasi unik dengan keahliannya di bidang ilmu eksakta. Pada tahun 1990, untuk pertama kalinya ide dan konsep tersebut diterbitkan dalam bentuk buku dan menjadi karya yang sangat monumental, yaitu al-Kitab wa al-Qur'an: Qira'ah Mu'ashirah (1990). Berbekal ilmu linguistik, Syahrur menawarkan gagasan

${ }^{15}$ Muhammad Syahrur, al-Kitab wa al-Qur'an; Qira'ah Mu'ashirah, (Damaskus: Dar al-Ahali liththiba'ah wa al-Nasyr wa al-Tauzi', 1992), cet. IV, h. 29-30

16 Ibid., h. 47-48

17 Ahmad Syarqawi Ismail, Rekonstruksi Konsep Wabyu Mubammad Syahrur, (Yogyakarta: eLSAQ Press, 2003), h. 45 dekonstruktif terhadap tema-tema ulum alQur'an, seperti anti-sinonimitas, proyek hermenutika, dan Teori Batas. ${ }^{18}$ Menurut penelitian, sejak pertama kali buku ini diterbitkan penjualannya sampai ribuan eksemplar dan dicetak beberapa kali untuk memenuhi permintaan dari dalam maupun luar negeri, sehingga sangat pantas buku ini dinobatkan sebagai the best seller. ${ }^{19}$

Karya Syahrur yang kedua dengan judul Dirasat Islamiyyah Mu'ashirah fi alDaulah wa al-Mujtama (1994), masih konsisten memakai pendekatan dan metodologi seperti buku yang pertama. Buku ini mengangkat isu utama tentang konsep hidup berbangsa dan bernegara. Lalu, Syahrur menegaskan bahwa perbedaan cara pandang itu adalah suatu hal yang biasa dan menanggapi secara ilmiah berbagai kritikan para penentangnya yang diarahakan pada buku pertamanya (alKitab wa al-Qur'an: Qira'ab Mu'ashirab). Buku keduanya ini juga langsung mendapatkan tanggapan dari Munir alSyawwaf dengan mempublikasikan sebuah buku yang berjudul Tahafut al-Dirasat alMu'ashirah fi al-Daulah wa al-Mujtama'. Menurutnya, pendekatan ilmu dan analisa eksakta yang digunakan oleh Syahrur sangat tidak sesuai dengan karakteristik alQur'an, sehingga bisa menghasilkan pemahaman yang salah. ${ }^{20}$

Berbagai serangan negatif yang datang tidak membuatnya terpuruk, sebaliknya Syahrur semakin bergairah untuk mengeksplorasi wacana keislamannya dengan menghasilkan karya baru berjudul al-Islam wa al-Iman: Manzuma al-Qiyam (1996). Disini Syahrur mencoba merumuskan kembali kaidah pokok keimanan yang sudah diwariskan dan

\footnotetext{
${ }^{18}$ Muhammad Syahrur, al-Kitab wa al-Qur'an; Qira'ah Mu'ashirah, Op.Cit., h. 46-48

19 A. Khudhori Saleh, Pemikiran Islam

Kontemporer, (Yogyakarta: Jendela, 2003), h. 295

20 Dikutip dari http://www.shahrour.org pada hari Selasa 1 September 2015
} 
menghasilkan sebuah kesimpulan baru yang berbeda dengan para ulama terdahulu. Kemudian, Syahrur juga menyinggung bagaimana Islam itu berbicara tentang strategi politik yang selama ini masih menjadi perdebatan dikalangan umat Islam. ${ }^{21}$

Karya Syahrur berikutnya berjudul Masyru'al-Amal al-Islam (1999) muncul atas permintaan dari Forum Dialog Islam Internasional yang berisi proposal perjanjian Islam untuk aksi abad 21 dengan pembahasan yang sesuai dengan konsep berfikirnya. Adapun persembahan terakhir yang ditulis Syahrur adalah Nahwa Ushul Jadidah li al-Fiqh al-Islami (2000). Dalam buku ini Syahrur mencoba untuk menetapkan metodologi dan pendekatan baru tentang kajian fikih sebagai bahan komparasi terhadap rumusan fikih para ulama klasik yang dianggap terlalu mendoktrin pemikiran para sarjana Islam sampai saat ini. Melalui konsep fikihnya yang baru, Syahrur ingin menyadarkan bahwa ajaran Islam itu pasti selalu relevan dan dibutuhkan pada setiap masa meskipun telah banyak terjadi perubahan. ${ }^{22}$

Publikasi buah pikiran Syahrur bukan hanya dengan buku saja, tetapi juga dalam bentuk diskusi ilmiah atau media publikasi melalui artikel yang tampil di surat kabar terkemuka di berbagai negara. Bahkan, Charles Kuzman mengumpulkan dan menyunting ulang beberapa artikel Syahrur tersebut untuk dijadikan sebuah buku yang berjudul Liberal Islam: a Source Book (New York \& Oxford: Oxford University Press, 1998). ${ }^{23}$

\section{ASUMSI BERFIKIR METODO- LOGIS MUHAMMAD SYAHRUR}

${ }^{21}$ Muhammad Syahrur, al-Islam wa al-Iman: Manzumah al-Qiyam, (Damaskus: Dar al-Ahali li alThiba'ah wa al-Nasyr wa al-Tauzi', 1996), h. 23-24

${ }_{22}$ Muhammad Syahrur, Nahwa Ushul Jadidah li al-Fiqhi al-Islami, (Damaskus: Dâr al-Ahâlî liththibâ'ah wa al-Nasyr wa al-Tauzî', 2000), h. 21.

${ }^{23}$ Ahmad Syarqawi Ismail, h. 51
Sebuah teori memyebutkan, setiap kegiatan intelektual yang memancar dari suatu kegelisahan tidak dapat dipisahkan dari problematika sosial yang melingkupinya. Dengan kata lain, sebuah bentuk pemikiran yang muncul memiliki relasi signifikan dengan realitas sosial sebagai respon terhadap berbagai fenomena yang berkembang di masyarakat. Syahrur dalam mengkonstruksi pemikirannya, khususnya yang terkait dengan masalah keislaman tidak lepas dari teori ini. Ide-idenya muncul setelah secara sadar mengamati perkembangan dalam tradisi ilmu-ilmu keislaman kontemporer.

Menurut Syahrur, peradaban Islam sejak permulaan abad ke-20 masih saja menyuguhkan Islam sebagai prinsip dan etika, tetapi tidak menyentuh dimensi filosofis dalam akidah Islam. Peradaban ini dibangun di atas berbagai doktrin dan ajaran yang dianggap bagian dari Islam, padahal landasan itu sudah perlu untuk dikaji ulang. Dengan berbagai kendala tersebut, terjadilah stagnasi dan ketidakmampuan memecahkan permasalahan yang fundamental dalam pemikiran Islam, karena masih dipenuhi berbagai taqlîd tentang konsep qadhâa dan qadar, faham kelompok, negara demokrasi, ilmu pengetahuan, masalah sosial ekonomi, dan penafsiran terhadap sejarah. $^{24}$

Peradaban Islam dalam pandangan Syahrur juga tidak produktif dalam menghasilkan pemikiran baru dalam Islam dengan mengadopsi nilai-nilai modernitas, baik dari bentuk maupun isinya, tanpa keluar dari haluan akidah Islam. Menurutnya, pemikiran Islam kontemporer memiliki problemaproblema sebagai berikut:

1. Tiadanya petunjuk metodologis dalam pembahasan ilmiah tematik yang ditulis oleh orang Islam terhadap penafsiran ayat-ayat suci al-Qur'an

${ }^{24}$ Muhammad Syahrur, al-Kitâb wa al-Qur'ân, h. $29-30$ 
yang diwahyukan kepada Nabi Muhammad SAW. Padahal, syarat utama dalam pengkajian ilmiah adalah dengan pandangan obyektif terhadap sesuatu tanpa pretensi dan simpati yang berlebihan.

2. Adanya penggunaan produk hukum masa lalu untuk diterapkan dalam persoalan kekinian. Misalnya, pemikiran hukum tentang wanita. Untuk itulah perlu adanya fikih dengan metodologi baru yang tidak hanya terbatas pada al-fuqahâ' al-khamsah.

3. Tidak adanya pemanfaatan dan interaksi dengan filsafat humaniora (alfalsafah al-insâniyyah). Hal ini disebabkan oleh adanya dualisme ilmu pengetahuan, yakni Islam dan non Islam. Tidak adanya interaksi tersebut berakibat pada mandulnya pemikiran Islam.

4. Tidak adanya epistimologi (teori) Islam kontemporer yang valid. Hal ini berdampak pada fanatisme dan indoktrinasi mazhab-mazhab yang merupakan akumulasi pemikiran abadabad silam, sehingga pemikiran Islam menjadi sempit dan tidak berkembang. Bahkan, keterpurukan ini sering menyebabkan mereka dituduh kafir, murtad, atau zindik.

5. Produk-produk fikih yang ada sekarang sudah tidak relevan lagi dengan tuntutan modernitas, sehingga yang diperlukan adalah formulasi fikih baru. Kegelisahan semacam ini sebenarnya sudah muncul dari para kritikus, tetapi umumnya hanya berhenti pada kritik tanpa menawarkan alternatif baru. ${ }^{25}$

Bertolak dari beberapa problema di atas, maka Syahrur melakukan pembacaan baru terhadap kitab suci yang telah dijanjikan Allah SWT untuk selalu dijaga dengan berpatokan pada beberapa hal:
1. Kajian menyeluruh dan mendalam terhadap bahasa Arab dengan berlandaskan pada metode linguistik Abu Ali al-Farisi yang tercermin dalam pandangan dua tokohnya, Ibnu Jinni dan Abd al-Qahir al-Jurjani, di samping berpegang juga pada sya'ir-sya'ir Arab jahiliyah.

2. Bersandar pada produk akhir ilmu linguistik modern yang menyatakan bahwa bahasa manapun tidak memiliki karakter sinonim dan yang benar adalah sebaliknya. Syahrur menjelaskan bahwa sebuah kata dalam koridor historisitasnya akan mengalami dua alternatif proses, yaitu mengalami kehancuran atau membawa makna baru selain makna asalnya. Fenomena ini jelas terjadi dalam bahasa Arab. Sesuai dengan prinsip ini, kamus paling representatif yang dijadikan acuan pelacakan semantis adalah al-Maqâyîs fî̀ al-Lughah, karya Ibnu Faris, yang menolak adanya sinonimitas dalam bahasa. Meski demikian, Syahrur menggunakannya tanpa menafikan keberadaan kamus-kamus lainnya.

3. Jika Islam bersifat relevan pada setiap ruang dan waktu, maka harus dipahami bahwa kitab suci yang diturunkan kepada Nabi Muhammad SAW adalah untuk seluruh umat manusia yang hidup di abad dua puluh ini. Syahrur menganjurkan "Perlakukan al-Qur'an seolab-olah Nabi baru meninggal kemarin". Ada tuntutan untuk memposisikan hanya al-Kitâb saja yang layak untuk disakralkan karena berasal dari Allah SWT, sedangkan produk tafsir yang merupakan hasil karya manusia harus selalu berubah supaya relevan dengan konteks apapun.

4. Allah SW'T tidak membutuhkan petunjuk apapun, sehingga menurunkan al-Kitâb kapada manusia yang untuk memahaminya sudah disesuaikan dengan kemampuan akal dan kapasitas pemahaman mereka. Media tersebut

${ }^{25}$ Ibid., h. 30-32

Perada: Jurnal Studi Islam Kawasan Melayu, Vol. 3, No. 2, Desember 2020 
berupa linguistik Arab murni karena tidak ada kontradiksi antara bahasa dan pemikiran. Syahrur menolak pendapat yang menyatakan bahwa ada ayat yang tidak bisa dipahami, karena pemahaman terhadap al-Kitâb selalu bersifat relatif, historis, dan temporal.

5. Allah SWT telah meninggikan posisi akal dengan cara mengungkapkannya dalam firman-firmanNya. Oleh karena itu, Syahrur berasumsi bahwa tidak ada pertentangan antara akal dengan wahyu, dan tidak ada pertentangan antara wahyu dengan realitas yang berupa kebenaran informasi dan rasionalitas penetapan hukum.

Penghormatan terhadap akal manusia harus lebih diutamakan daripada penghor-matan terhadap perasaannya. Dengan kata lain, ijtihad-ijtihad Syahrur lebih menuntut pada kekuatan logika dan analisa daripada hanya memikirkan sensitifitas hati dan perasaan. ${ }^{26}$

\section{TAFSIR ATAS PERHIASAN TUBUH WANITA}

Bagi Syahrur, kajian tentang perhiasan tubuh wanita merupakan pembahasan penting yang akan membawa kepada pemahaman tentang batasan aurat wanita. Perhiasan ini terbagi menjadi tiga macam bentuk, yaitu:

1. Perhiasan benda merupakan perhiasan dengan menambahkan sesuatu kepada benda lain yang biasa dipakai oleh wanita, atau pada tempat lain dengan tujuan supaya terlihat lebih indah, seperti baju, rok, jilbab, cincin, gelang, kalung, atau anting. Bentuk perhiasan ini dijelaskan dalam firman Allah SWT:

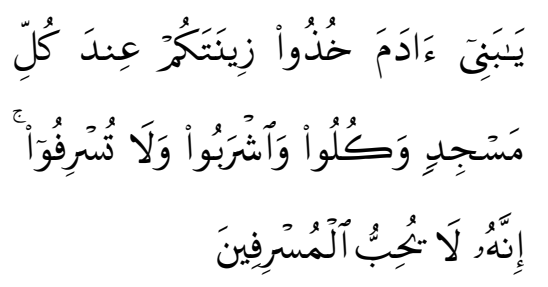

26 Ibid., h. 44-45
"Hai anak Adam, pakailah pakaianmu yang indah di setiap (memasuki) mesjid, makan dan minumlah, dan janganlah berlebih-lebihan. Sesunggubnya Allah tidak menyukai orang-orang yang berlebih-lebihan" (Q.S. al-A'raf: 31)

2. Perhiasan tempat merupakan perhiasan yang dianugerahkan oleh Allah SWT yang lazim terdapat pada seluruh tubuh wanita. Perhiasan tempat ini dibagi menjadi dua, yaitu bagian dari tubuh yang tampak secara alami (al-zinah alzhabirah) dan yang tidak tampak secara alami (al-zinah al-makhfiyyah). Bentuk perhiasan ini dijelaskan dalam firman Allah SWT:

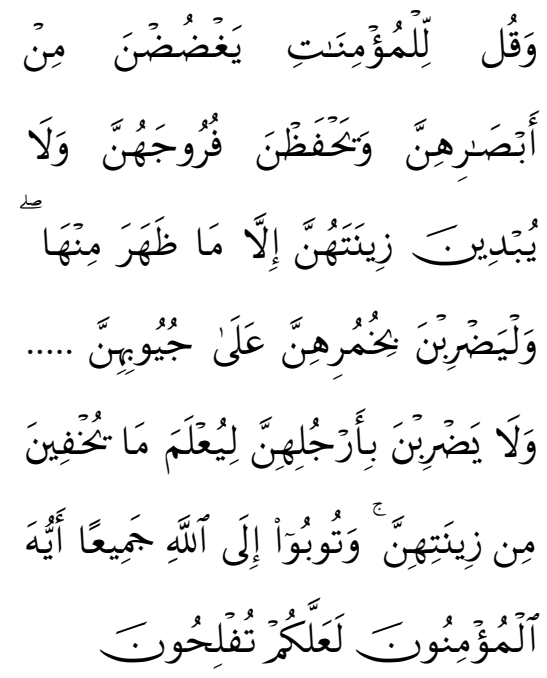

"Katakanlah kepada wanita yang beriman hendaklah mereka menahan pandangannya dan kemaluannya, dan janganlab mereka menampakean perbiasannya, kecuali yang (biasa) nampak dari padanya, dan bendaklah mereka menutupkan kain kudung ke dadanya" (Q.S. al-Nur: 31)

3. Perhiasan gabungan antara yang bersifat benda dan tempat. Perkembangan zaman dan ilmu pengetahuan akan membuat manusia semakin menyempurnakan bentuk perhiasannya, baik dari sisi benda maupun tempat. Jadi, perhiasan yang dimaksud disini bisa dalam bentuk 
benda, seperti anting, kalung, gelang, dan sejenisnya, atau berupa tempat yang terdiri dari seluruh bagian tubuh wanita. Bentuk perhiasan ini diumpamakan dan dijelaskan oleh Allah SWT dalam firmanNya:

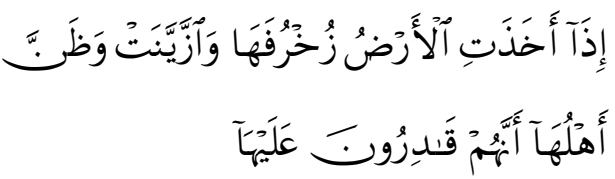

"Hingga apabila bumi itu telab sempurna keindahannya dan memakai (pula) perbiasannya, dan pemilik-permliknya mengira bahwa mereka pasti menguasasinya" (Q.S. Yunus: 24) ${ }^{27}$

Berdasarkan bentuk perhiasan tempat di atas, maka menurut Syahrur tubuh wanita terbagi dua. Pertama, bagian tubuh yang tampak secara alami (al-zinah al-zhabirah), sebagaimana Allah SWT berfirman:
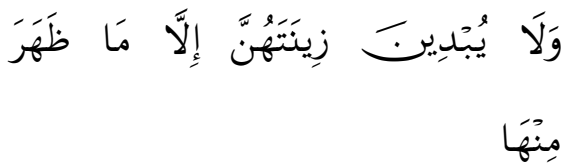

"Janganlah mereka menampakkan perbiasannya, kecuali yang (biasa) nampak dari padanya" (Q.S. al-Nur: 31)

Menurut Syahrur, manusia diciptakan oleh Allah SWT dalam keadaan tanpa sehelai benang pun atau telanjang. Makanya, ketika menciptakan bagian tubuh wanita, seperti kepala, perut, punggung, dua tangan, dan dua kaki, Allah SWT memperlihatkan semuanya tanpa ada yang ditutupi. Inilah yang dimaksud dengan perhiasan yang secara alami bisa dilihat tanpa usaha apapun. Namun, pemahaman yang benar terhadap ayat di atas adalah ada bagian perhiasan dari tubuh wanita yang harus disembunyikan

${ }^{27}$ Muhammad Syahrur, Nahwa Ushûl Jadìdah lilfiqh al-Islâmî, h. 362-363 dan hanya bisa dilihat oleh orang-orang tertentu saja. ${ }^{28}$

Kedua, bagian tubuh yang tidak tampak secara alami (al-zinah al-makbfiyyah), yaitu bagian yang tersembunyi. Kemudian, dikenal juga dengan istilah al-juyub, atau sesuatu yang berlubang (bercelah). Menurut Syahrur, Allah SWT menyembunyikan bagian ini pada susunan bentuk tubuh wanita. Kata al-juyub (الجُيُوْبُبُ)

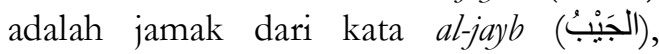
berasal dari kata جَبَب, seperti dalam perkataan أَقَقَيْصَنَ, artinya aku melubangi bagian saku atau aku membuat saku pada baju. Lubang atau celah yang dimulai dari kemaluan, pantat, bagian antara payudara, bagian bawah payudara, dan bagian bawah ketiak, merupakan tingkatan dari istilah al-juyub. Sedangkan, hukum untuk menutupi kategori al-juyub ini adalah wajib bagi setiap wanita beriman apalagi yang sudah baligh dan mukallaf. ${ }^{29}$ Ketentuan ini sesuai dengan firman Allah SWT:

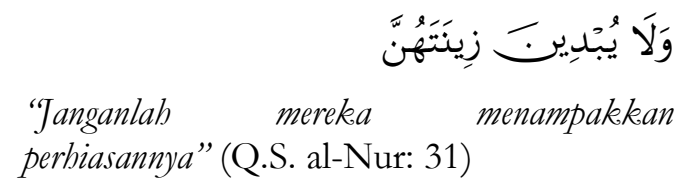

Menampakkan (al-ibda') biasanya disandingkan dengan lawan katanya yaitu menyembunyikan, sebagaimana disebutkan dalam firmanNya:

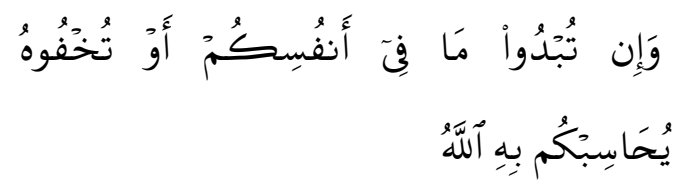

"Tika kamu menampakkan apa yang ada di dalam hatimu atau kamu menyembunyikan, niscaya Allab akan membuat perbitungan dengan kamu tentang perbuatanmu itu" (Q.S. alBaqarah: 284)

\footnotetext{
${ }^{28}$ Muhammad Syahrur, al-Kitâb wa al-Qur'ân; Qirâ'ab Mu'âsbirah, h. 606

${ }^{29}$ Ibid., h. 606-607
} 
Selain itu, kata al-ibda' juga cuma ditujukan pada objek yang berakal, seperti dalam firmanNya:

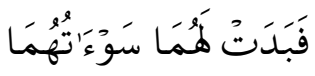

"Lalu nampaklah bagi keduanya (Adam dan Hawa) aurat-auratnya” (Q.S. Thaha: 121)

Ada yang menentang argumentasi Syahrur melalui pernyataan, "Bukankah mulut, hidung, kedua mata, dan kedua telinga termasuk dalam kategori al-juyub?" Syahrur menjawab, "Benar, tetapi bagianbagian tersebut adalah al-juyub yang tampak karena terletak di wajah dan bagian kepala merupakan bagian yang sudah seharusnya diperlihatkan karena paling menonjol secara fisik dan berfungsi sebagai ciri khas manusia. ${ }^{30}$

Secara eksplisit Allah SWT juga telah menyebutkan salah satu bagian dari aljuyub dan harus dipastikan terhindar dari pandangan mata, seperti dalam firmanNya:

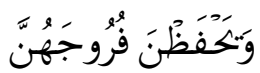

"Dan bendaklab mereka (para wanita) menjaga kemaluannya" (Q.S. al-Nur: 31)

Syahrur memahami bahwa kemaluan dan pantat wanita (termasuk lipatan pada pantat) masuk kategori aljuyub yang hanya bisa dilihat oleh suami saja. Bagian inilah yang oleh para ulama ditetapkan sebagai aurat berat. ${ }^{31}$

Adapun bagian antara dan bawah payudara tidak dipungkiri lagi bagian tersebut adalah termasuk kategori al-juyub. Bahkan, para ahli tafsir menetapkan bahwa bagian tersebut adalah satu-satunya bagian al-juyub yang dimaksud oleh ayat. Pemahaman didukung fakta bahwa para wanita Arab ketika surat al-Nur ayat 31 diturunkan tidak melakukan sesuatu, kecuali hanya menutupi bagian payudara

\footnotetext{
${ }^{30}$ Ibid., h. 607

${ }^{31}$ Muhammad Syahrur, Nahwa Ushûl Jadîdah lilfiqh al-Islâmî, h. 364
}

dengan menggunakan kudung mereka yang diulurkan dari kepala sekedarnya saja. Hal ini dilakukan karena para wanita Arab pra-Islam dan pada masa Nabi Muhammad SAW mengenakan pakaian yang longgar, tipis, dan sederhana dengan bagian dada terbuka sebagai bentuk adaptasi terhadap kondisi lingkungan padang pasir dan Badui. Jadi, secara alami mereka membiarkan bagian dada terbuka, sedangkan bagian al-juyub yang lain sudah pasti berada dalam keadaan tertutup. ${ }^{32}$

Allah SWT telah menjelaskan empat bagian al-juyub, yaitu kemaluan, pantat, bagian antara payudara, dan bagian bawah payudara, pada surat al-Nur ayat 31 . Berikutnya, satu pembahasan lagi yang terkait dengan al-juyub, yaitu bagian yang terletak di bawah ketiak, sebagaimana disebutkan dalam dua firman Allah SWT:

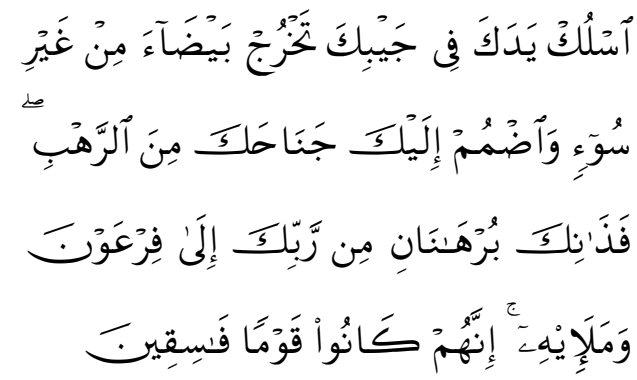

"Masukkanlah tanganmu ke leher bajumu, niscaya ia keluar putih tidak bercacat bukan karena penyakit, dan dekapkanlah kedua tanganmu (ke dada) mu bila ketakutan, maka yang demikian itu adalah dua mukjizat dari Tubanmu (yang akan kamu hadapkan kepada Fir'aun dan pembesar-pembesarnya). Sesunggubnya mereka adalah orang-orang yang fasik" (Q.S. al-Qashash: 32)

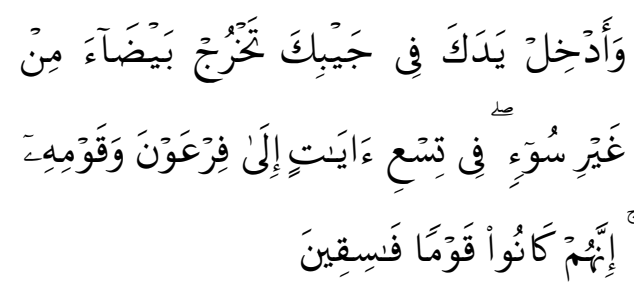

${ }^{32}$ Ibid., h. 364-365 
'Dan masukkanlah tanganmu ke leher bajumu, niscaya ia akan ke luar putib (bersinar) bukan karena penyakit. (Kedua mukjizat ini) termasuk sembilan buah mukjizat yang akan dikemukakan) kepada Fir'aun dan kaumnya. Sesunggubnya mereka adalah kaum yang fasik." (Q.S. al-Naml: 12)

Berdasarkan dua ayat tersebut bisa disimpulkan bahwa Nabi Musa AS diminta oleh Allah SWT agar memasukkan dan mengapit tangan pada bagian bawah ketiaknya dari bajunya yang terbuka di bagian dada, dan tidak ada alternatif lain baginya selain mentaati perintah Tuhannya dengan melakukan hal itu. Kemudian, perhatikan bagaimana Allah SWT menggunakan kata أسنْلَ yang memiliki makna dasar "menelusuri", untuk menunjukkan bagian ketiak yang harus dituju oleh tangan, bukan sekedar meletakkan tangan di sembarang bagian celah tubuh. ${ }^{33}$ Hal ini bisa dilihat ketika menggabungkan kedua ayat di atas, seperti digambarkan dalam firman Allah SWT:

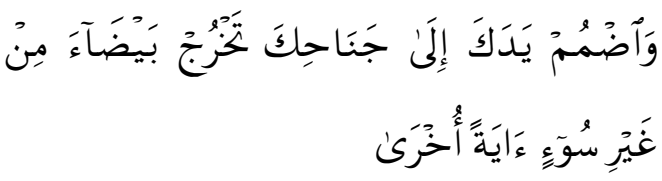

"Dan kepitkanlah tanganmu ke ketiakmu, niscaya ia ke luar menjadi putib cemerlang tanpa cacat, sebagai mukjizat yang lain (pula)" (Q.S. Thaha: 22)

\section{KRITIKAN TERHADAP PENAFSIR- AN MUHAMMAD SYAHRUR}

Kritikan terhadap Syahrur di awali dengan pandangannya yang membagi perhiasan wanita menjadi perhiasan benda, perhiasan tempat, dan perhiasan gabungan antara keduanya. Menurutnya, inilah hakikat sebenarnya yang dimaksud oleh ayat dan tidak terpikirkan oleh para ulama sebelumnya. Penyebab kekeliruan para ulama adalah selain kesalahan dalam memahami teori batas, juga karena menganalogikan sesuatu yang hadir

${ }^{33}$ Ibid., h. 365 berdasarkan sesuatu yang tidak ada. ${ }^{34}$ Akan tetapi, apa yang disampaikan oleh Syahrur tersebut perlu ditinjau ulang karena tidak ada ditemukan pendapat para ulama yang mengkategorikan perhiasan pada tiga bentuk ini.

Perhiasan itu biasanya identik dengan suatu benda yang ditambahkan ke benda lain atau ke tempat lain yang berfungsi untuk memperindahnya. Pengertian ini juga menunjukkan bahwa perhiasan itu bukanlah sesuatu yang sudah ada atau bawaan, melainkan dibuat terlebih dahulu. Modelnya pun disesuaikan dengan kebutuhan supaya berfungsi secara maksimal dan memuaskan pemakainya. Bahkan, seiring perkembangan zaman berbagai macam model perhiasan pun diciptakan untuk memperindah setiap bagian tubuh wanita. Para wanita berlomba-lomba untuk memakainya supaya terlihat lebih cantik dan menambah kepercayaan diri, seperti penjempit rambut, celak mata, lipstik, anting, kalung, gelang tangan dan kaki, dan lain-lain.

Bukti eksistensi perhiasan ini sebenarnya bisa dilihat dari tradisi sejak masa dahulu, di mana perhiasan wanita Arab itu ada yang tampak, seperti cincin, dan yang tersembunyi, seperti gelang kaki. Adanya pengakategorian perhiasan yang tampak dan yang tersembunyi ini menunjukkan bahwa setiap perhiasan yang dipakai oleh para wanita sangat erat kaitannya dengan aurat. Artinya tidak semua orang bisa melihat perhiasan yang dipakai itu pada beberapa bagian dari tubuh wanita. Terlihatnya perhiasan dari sisi yang seharusnya disembunyikan berarti sama saja dengan mengumbar aurat. Selain itu, perhiasan yang dipakai sebaiknya tidak terlalu berlebihan, apalagi sampai memancing orang lain untuk menggoda atau mengolok-oloknya.

Ketika merujuk ke dalam beberapa kitab tafsir, terlihat jelas bahwa para h. 608
${ }^{34}$ Muhammad Syahrur, al-Kitâb wa al-Qur'ân,

Perada: Jurnal Studi Islam Kawasan Melayu, Vol. 3, No. 2, Desember 2020 
mufassir tidak sependapat dengan apa yang disampaikan oleh Syahrur. Hamka memulai pandangannya tentang perhiasan dengan pengakuan Islam terhadap keindahan. Akan tetapi, hendaklah semua itu berasal dari kesadaran sebagai manusia yang dianugerahkan akal dan fikiran oleh Allah SWT dalam membuat sebuah keputusan, bukan karena mengikuti nafsu syahwat hewaniyahnya saja. Adapun mengumbar aurat apalagi bertelanjang, atau bertingkah menggiurkan seolah-olah memberikan isyarat yang menggoda lawan jenis bukanlah keindahan yang dimaksud oleh agama. ${ }^{35}$

Tidak jauh berbeda dengan Hamka, Quraish Shihab lebih spesifik lagi dengan melihat bahwa perhiasan itu pada dasarnya dapat membuat laki-laki tertarik. Ini disesuaikan dengan pemahaman dari redaksi ayat bahwa perhiasan itu bisa berupa gelang kaki, suara yang keluar dari sikapnya, dan wewangian yang mereka pakai. ${ }^{36}$

Penjelasan di atas memberikan gambaran bahwa pendapat Syahrur tentang pembagian perhiasan wanita sudah berada dalam konteks yang pantas untuk ditolak. Ini dibuktikan dengan pandangan para ulama yang tidak membagi perhiasan wanita menjadi tiga macam, tetapi mereka lebih cenderung memahami perhiasan itu sesuai dengan fungsinya untuk memperindah, seperti gelang kaki, suara, atau wewangian. Selain jauh berbeda dengan pendapat para ulama, pola yang digunakan Syahrur dalam menyimpulkan pembagian perhiasan wanita juga semakin menegaskan kesempitan pola pikir Syahrur.

Berikutnya yang kedua terkait dengan penafsiran Syahrur yang menyatakan bahwa tubuh wanita terbagi dua, yaitu sisi yang tampak secara alami yang terdiri dari kepala, perut, punggung, dua kaki, dan dua tangan, sedangkan sisi yang tidak tampak secara alami (al-juyub) yang terdiri dari kemaluan, pantat, antara payudara, bawah payudara, dan bagian bawah ketiak. Jadi, Syahrur membedakan antara perhiasan wanita dengan tubuh wanita. Sementara itu, menurut para ulama perhiasan yang dimaksud oleh ayat adalah tubuh wanita itu sendiri. Bahkan, ada di antara ulama yang menyatakan bahwa tubuh wanita itu hanya terdiri dari satu bagian saja.

Pandangan Syahrur tersebut dibantah dengan penjelasan al-Maraghi tentang perhiasan wanita ini di dalam tafsirnya. Ia menyarankan hendaklah para wanita tidak memperlihatkan perhiasannya kepada laki-laki asing, kecuali sesuatu yang biasa terlihat dan tidak perlu ditutupi, seperti cincin dan lipstik, maka dalam hal ini mereka tidak akan mendapatkan balasan buruk. Akan tetapi, kalau yang tampak itu adalah perhiasan yang seharusnya tidak diperlihatkan, seperti anting, gelang tangan atau gelang kaki, maka dilarang untuk mengumbarnya secara sembarangan karena perhiasan tersebut berada diposisi tubuh yang haram untuk dilihat dan bisa menimbulkan dosa, kecuali bagi sebagian orang seperti penjelasan ayat. ${ }^{37}$

Pemaparan al-Maraghi di atas diperkuat oleh Hasbi ash-Shiddiqy yang melarang para wanita menampakkan hiasan-hiasan badannya yang terletak di tempat yang dilarang terbuka. Tegasnya, bagian badan yang menjadi tempat diletakkannya perhiasan jangan sampai ditampakkan, seperti leher yang menjadi tempat letaknya kalung, kecuali hiasan
35 Hamka, Tafsir al-Azhar, (Jakarta: PT. Pustaka Panjimas, 1988), juz. 17, h. 183

36 Muhammad Qurasih Shihab, Tafsir alMisbab: Pesan, Kesan, dan Keserasian al-Qur'an, (Jakarta: Lentera Hati, 2002), vol. 9, h. 327
${ }^{37}$ Ahmad Musthafa al-Maraghi, terj. Tafsir alMaraghi, (Semarang: CV. Toha Putra Semarang, 1989), juz 18, h. 175 
yang biasa kelihatan, seperti lipstik yang ada di muka dan cincin di telapak tangan. ${ }^{38}$

Selanjutnya, Quraish Shihab mempunyai pandangan tersendiri yang bisa dikatakan sejalan dengan pendapat dua mufassir sebelumnya. Menurutnya, bagian tubuh wanita itu hanya ada satu, yaitu bersifat khilqiyyah atau yang melekat pada tubuh seseorang. Hanya saja Quraish Shihab merincikan bagian khilqiyyah ini terbagi menjadi dua, yaitu yang dapat dibuka dan ditoleransi karena apabila ditutup mengakibatkan kesulitan bagi wanita, seperti wajah, kedua telapak, dan kedua telapak kaki, dan lawannya yang harus ditutup, seperti bagian atas kedua betis, kedua pergelangan, kedua bahu, leher, bagian atas dada, dan kedua telinga. ${ }^{39}$

Penjelasan di atas sebenarnya membawa pada pemahaman yang jauh lebih komprehensif tentang pembagian tubuh wanita, sehingga kesimpulan yang dibuat oleh Syahrur menjadi terkesan lebih sempit. Syahrur membagi tubuh wanita menjadi dua bagian, yaitu bagian yang terbuka secara alami dan bagian yang tertutup secara alami (al-juyub). Akan tetapi, dari penjelasan para mufassir bisa didapatkan tiga cara lain yang lebih logis untuk mengetahui pembagian tubuh wanita, yaitu berdasarkan perhiasan yang melekat padanya, berdasarkan penjelasan tentang hukum dan akibat yang akan diterima apabila melanggarnya, dan berdasarkan bagian yang dapat ditoleransi karena bisa mengakibatkan kesulitan.

Adapun yang ketiga adalah perbedaan pendapat antara para ulama dengan Syahrur tentang al-juyub (bagian yang berlubang dan bercelah), yang terdiri dari sisi diantara payudara, bawah payudara, bawah ketiak, kemaluan, dan pantat. Belum ada ditemukan pendapat

38 Teungku Muhammad Hasbi ashShiddiqy, (Jakarta: Pustaka Rizki Putra Semarang, 1995), jil. 4, h. 2724

39 Muhammad Qurasih Shihab, Tafsir alMisbah, vol. 9, h. 330-331 yang benar-benar sama dengan Syahrur tentang maksud al-juyub tersebut, apalagi yang sampai mengakategorikannya sebagai batas minimal aurat wanita. Mayoritas ulama lebih cenderung menyatakan bahwa yang dimaksud dengan al-juyub itu adalah bagian dada atau sekitar payudara.

Ini bisa dilihat dari penjelasan Hasbi ash-Shiddiqy yang mengartikan al-juyub dengan dada. Kalau demikian, maka yang diperintahkan untuk ditutup itu adalah dada saja dengan mengulurkan kudungnya atau menggunakan baju yang bisa menyembunyikan bagian tersebut tanpa ada perintah untuk menutup bagian lain. Ini dilakukan karena orang-orang Arab dahulu memakai baju yang lehernya terbuka lebar dan kelihatan buah dadanya. Sebenarnya kudung itu merupakan pakaian wanita yang biasa dipakai pada zaman jahiliyah. Akan tetapi, leher baju para wanita Arab dahulu adalah lebar dan menampakkan dada karena mereka mengulurkan kudungnya kebelakang. Berdasarkan fakta tersebut, supaya bagian dadanya bisa tertutup dengan sempurna, maka mereka diperintahkan oleh al-Qur'an untuk menurunkan kudungnya kedepan. ${ }^{40}$

Begitu juga dengan Hamka yang mengatakan bahwa al-juyub itu artinya celah dibagian dada yang dapat memperlihatkan pangkal payudara. Hal ini mengisyaratkan bagaimana hebatnya peranan yang diambil payudara dalam menimbulkan syahwat. Oleh karena itu, diperintahkan kepada wanita beriman untuk memakai selendangnya sampai menutupi seluruh bagian dada. ${ }^{41}$ Selain itu, Quraish Shihab mengartikan al-juyub itu dengan lubang yang ketika memakai baju digunakan untuk memasukkan kepala. Maksudnya, pada bagian ini sering bisa menampakkan belahan dada. ${ }^{42}$

\footnotetext{
40 Teungku Muhammad Hasbi ashShiddiqy, jil. 4, h. 2727

${ }^{41}$ Hamka, Tafsir Al-Ažbar, juz. 17-18, h. 180

42 Muhammad Qurasih Shihab, Tafsir alMisbah, vol. 9, h. 328
} 
Pandangan para mufassir di atas juga senada dengan al-Maraghi yang lebih cenderung mengartikan al-juyub ini dengan dada bagian atas di bawah leher. Para wanita dianjurkan untuk mengulurkan kudungnya supaya tidak terlihat sedikitpun leher apalagi dadanya. Hal ini untuk menghindari tradisi wanita jahiliyah yang sering mengulurkan kudungnya kebelakang sampai ke punggung, sehingga terbuka pada bagian leher dan menampakkan dadanya. Aisyah RA berkata, "Semoga Allah SWT mengasihani kaum wanita mubajirat yang pertama karena ketika diturunkan ayat yang memerintahkan mereka untuk menutup dadanya, maka mereka segera mengambil pakaian bulu dan berkerudung dengannya". ${ }^{43}$

Dari semua pendapat mufassir tersebut, tidak ada satupun yang sejalan dengan Syahrur yang mengkategorikan bagian al-juyub itu adalah kemaluan, pantat, bagian antara payudara, bagian bawah payudara, dan bagian bawah ketiak. Sebaliknya, mayoritas mereka mengartikan al-juyub hanya dengan bagian dada atau sekitar payudara. Bahkan, hal ini semakin diperkuat dengan salah satu pernyataan dari Syahrur bahwa bagian antara dan bawah payudara tidak dipungkiri lagi bagian tersebut adalah termasuk kategori al-juyub. Menurutnya, para ahli tafsir telah menetapkan bahwa bagian tersebut adalah satu-satunya bagian al-juyub yang dimaksud oleh ayat. Pemahaman ini juga didukung fakta bahwa kebiasaan para wanita Arab adalah mengenakan pakaian yang longgar dengan bagian dada terbuka dan mengulurkan kudungnya ke dada sekedarnya saja. ${ }^{44}$ Penjelasan ini secara tidak langsung tentunya memberikan gambaran bagaimana inkonsistensi Syahrur dalam menuangkan pemikirannya.

43 Ahmad Musthafa al-Maraghi, Tafsir AlMaraghi, juz. 18, h. 175-176

${ }^{44}$ Muhammad Syahrur, Nahwa Ushûl Jadîdah lilfiqh al-Islâmî, h. 364
Pengkategorian Syahrur dengan adanya bagian al-juyub ini sebenarnya bisa menjadi indikasi kalau ayat tersebut diturunkan untuk memerintahkan para wanita Arab zaman dahulu yang keluar rumah dengan pakaian mini supaya menutup auratnya dan berpakaian sesuai dengan kebiasaan masyarakat sekitar, sehingga terhindar dari gangguan dan fitnah. Padahal, dalam konteks sejarah (teori yang digunakan Syahrur), bisa dibuktikan bahwa para wanita tersebut telah menutup tubuhnya dengan pakaian hampir secara sempurna.

Konsep pembagian perhiasan dan tubuh wanita tampak sudah jauh melenceng dari apa yang disimpulkan oleh para ulama. Semua itu merupakan akibat dari kurangnya perangkat keilmuan yang dimiliki Syahrur dalam mengkaji teks alQur'an, sehingga ia memberikan porsi yang terlalu besar kepada logika untuk membuat sebuah keputusan. Apalagi, adanya pengkategorian daerah al-juyub sebagai aurat yang wajib untuk ditutupi membuatnya semakin berbahaya. Sebagai akibatnya akan menimbulkan pemahaman negatif tentang kebolehan untuk membuka daerah-daerah selainnya yang mempunyai posisi sama dengan kategori al-juyub yang dikonsepkan oleh Syahrur. Sebagai contoh, ketika ada wanita keluar rumah hanya menggunakan pakaian dalam saja akan dianggap hal biasa dan tidak dianggap bertentangan dengan aturan Allah SWT, atau ada yang tidak menggunakan penutup kepala dan menampakkan tindik di pusarnya, maka hal tersebut juga akan dipandang tidak masalah.

Secara umum, penyebab berbagai kerancuan berfikir Syahrur dipengaruhi dan diakibatkan oleh latar belakang kehidupannya yang banyak dihabiskan di negara-negara Barat, bergaul dengan masyarakatnya, dan berbaur dengan kebudayaan mereka, yang mayoritas bertolak belakang dengan syari'at Islam. Pola kehidupan masyarakat Barat tersebut 
sangat kental dengan paham liberal dan ateis, di mana akal dijadikan sebagai alat untuk mencari solusi permasalahan dan menjawab berbagai tantangan zaman. Oleh karena itu, tidak mengherankan ketika Syahrur menetapkan pembagian perhiasan tubuh wanita disesuaikan dengan situasi, kondisi, dan kebutuhan suatu masyarakat tempatnya bergaul.

Selain itu, riwayat pendidikan Syahrur basicnya adalah teknik dan lebih dikenal sebagai seorang ahli di bidang Mekanika Tanah dan Geologi, yang tidak ada kaitannya dengan ranah studi Islam. Syahrur memang pernah belajar bahasa Arab secara otodidak dan dibantu oleh sahabatnya Ja'far Dak al-Bab, namun dalam menafsirkan al-Qur'an banyak ilmuilmu lain yang tidak dikuasai oleh Syahrur, seperti ilmu al-Qur'an, ilmu hadis, dan ilmu ushul fiqh. Oleh karena itu, tidak mengherankan ketika menetapkan pembagian perhiasan tubuh wanita Syahrur tidak tegas menjelaskan tentang munasabah ayat dengan ayat, atau dengan hadis, apalagi mengkorelasikannya dengan kaidah ushul fiqh.

\section{KESIMPULAN}

Menurut Muhammad Syahrur, perhiasan tubuh wanita di bagi menjadi perhiasan benda, perhiasan tempat, dan perhiasan gabungan antara keduanya. Adapun perhiasan tempat itu merupakan tubuh wanita yang dikategorikan menjadi bagian tubuh yang tampak secara alami dan yang tidak tampak secara alami. Kemudian, bagian tubuh yang tidak tampak secara alami ini disebut dengan istilah al-juyub yang terdiri dari kemaluan, pantat, bagian antara payudara, bagian bawah payudara, dan bagian bawah ketiak. Bagian al-juyub mendapatkan perhatian lebih dari Syahrur karena terkait langsung dengan batasan aurat wanita. Pembacaan ulang yang dilakukan oleh Syahrur terhadap ayat-ayat suci al-Qur'an dianggap keliru karena sangat minim pengetahuan tentang Islam. Di samping itu, kebiasaannya berbaur dengan budaya barat dan backround keilmuannya sebagai seorang teknokrat juga mengurangi rasa percaya pada sosok Syahrur. Dominannya penggunaan akal membuat penafsirannya dianggap telah menghilangkan sakralitas nash-nash agama. Selain itu, kerancuan berfikirnya terlihat ketika ada inkonsistensi dalam menetukan sebuat pendapat tentang bagian al-juyub. Puncaknya, ketika tidak ada ditemukan penjelasan para ulama dan mayoritas mufassir yang sesuai dengan Syahrur tentang pembagian perhiasan tubuh wanita, padahal mereka menggunakan dalil yang sama. []

\section{DAFTAR PUSTAKA}

Abdullah, Muhammad Amin, 'Metode Kontemporer dalam Penafsiran alQur'an', dalam Jurnal Studi IlmuIlmu al-Qur'an dan Hadis, Vol. 13, No. 1, Januari 2012.

Abu Zayd, Nasr Hamid, Mafhûm al-Nash Dirâsah fì 'Ulûm al-Qur'ân, (Kairo: alHai'ah al-Mishriyah al-'Âmmah li alKitâb, 1993).

Almirzanah, Syafa'atun dan Sahiron Syamsuddin, Upaya Integrasi Hermeneutika dalam Kajian Qur'an dan Hadis (Teori dan Aplikasi), (Yogyakarta: Lembaga Penelitian UIN Sunan Kalijaga, 2012).

Arikunto, Suharsini, Prosedur Penelitian: Suatu Pendekatan Praktik, (Jakarta: Rineka Cipta, 1993).

Arkoun, Muhammad, terj. Berbagai Pembacaan al-Qur'an, (Jakarta: INIS, 1997).

Azzam, Abdul Aziz, al-Qawâid al-Fiqhiyyah, (Kairo: Dâr al-Hadîts, 2005).

Furchan, Arif dan Agus Maimun, Studi Tokob: Studi Penelitian Mengenai Tokoh, (Yogyakarta: Pustaka Pelajar, 2005).

Hamka, Tafsir al-Azhar, (Jakarta: PT. Pustaka Panjimas, 1988). 
Husaini, Adian., dan Abdurrahman alBaghdadi, Hermeneutika dan Tafsir AlQur'an, (Jakarta: Gema Insani, 2007).

Ismail, Ahmad Syarqawi, Rekonstruksi Konsep Wabyu Mubammad Syahrur, (Yogyakarta: eLSAQ Press, 2003).

Izzan, Ahmad, Metodologi Ilmu Tafsir, (Bandung: Tafakkur, 2009).

Al-Maraghi, Ahmad Mustafa, terj. Tafsir alMaraghi, (Semarang: CV. Toha Putra Semarang, 1989).

Mubarok, Ahmad Zaki, Pendahuluan; Pendekatan Strukturalisme Linguistik dalam Tafsir Kontemporer "ala" Mubammad Syahrur, (Yogyakarta: eLSAQ Press, 2007).

Muhadjir, Noeng, Metodologi Penulisan Kualitatif, (Yogyakarta: Rake Suarsiah, 2000).

Mustaqim, Abdul, Epistemologi Tafsir Kontemporer, (Yogyakarta: Lkis, 2012).

-----------, 'Konsep Poligami Menurut Mubammad Syahrur', dalam Jurnal Studi Ilmu-Ilmu Al-Qur'an dan Hadis, Vol. 8, No. 1, Januari 2007.

Saleh, A. Khudhori, Pemikiran Islam Kontemporer, (Yogyakarta: Jendela, 2003).

Shah, M. Aunul Abied dan Hakim Taufik, Islam Garda Depan: Mosaik Pemikiran Islam Timur Tengah, (Bandung: Mizan, 2001).

Shihab, Muhammad Quraish, Tafsir alMishbah: Kesan, Pesan, dan Keserasian al-Qur'an, (Jakarta: Lentera Hati, 2002).

Ash-Shiddiqy, Teungku Muhammad Hasbi, Tafsir al-Quranul Majid (Tafsir Annur), (Jakarta: Pustaka Rizki Putra Semarang, 1995).

Sukandi, Arif, Metode dan Analisis Penelitian, (Jakarta: PT. Glora Alsora Pratama, 1991).

Suprayogo, Imam dan Tobroni, Metodologi Penelitian Sosial-Agama, (Bandung: Remaja Rosdakarya, 2001).

Syahrur, Muhammad, al-Islâm wa al-Îmân: Manzuma al-Qiyâm, (Damaskus: Dâr
al-Ahâlî liththibâ'ah wa al-Nasyr wa al-Tauzî̀, 1996), cet. I.

------------, al-Kitâb wa al-Qur'ân; Qirâ'ah Mu'âshirah, (Damaskus: Dâr al-Ahâlî liththibâ'ah wa al-Nasyr wa alTauzî', 1992), cet. IV.

-------------, Nahwa Ushûl Jadîdah lilfiqh alIslâmî, (Damaskus: Dâr al-Ahâlî liththibâ'ah wa al-Nasyr wa alTauzî', 2000), cet. I.

al-Taubah, Gazi, 'Syahrur Yulawwi A'naq alNusus li Agrad Gair al-Ilmiyyah wa alTaftaqiru ila al-Bara'ab', dalam Majalah al-Mujtama', No. 1302, 26 Mei 1998.

Woelandt, Routraud, Tafsir al-Qur'an Masa Awal Modern dan Kontemporer', dalam Jurnal Afkar, Edisi No. 18, 2004.

Zed, Mestika, Metode Penelitian Kepustakaan, (Jakarta: Yayasan Obor Indonesia, 2004).

http://www.shahrour.org [accessed Thursday 14 July 2020]. 